Article Progress Time Stamps
Article Type: Research Article
Manuscript Received: $15^{\text {th }}$ March, 2020
Review Type: Blind Final
Acceptance: $24^{\text {th }}$ June, 2020
CrossREF Member Listing :: ttps://www.crossref.org/06members/50go-live.html

\title{
Factors Influencing Job Satisfaction of Librarians in Federal University Libraries in South-East Geo-Political Zone of Nigeria
}

\author{
1Edom, Eunice Uchechi Ph.D., 20nuegbu, Remigius Chinedu Ph.D. \& ${ }^{3}$ Leo-Ogbonna, Nkechi G. Ph.D \\ ${ }^{1}$ The library Imo State Polytechnic, Umuagwo, Nigeria \\ 2Department of Business Administration and Management, Imo State Polytechnic, Umuagwo, Nigeria \\ ${ }^{3}$ The library Imo State University, Owerri, Nigeria

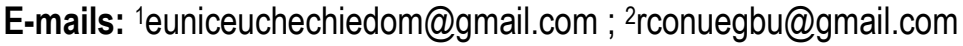

\begin{abstract}
This study examined factors influencing job satisfaction of librarians in libraries of federal universities in South-East geo-political zone of Nigeria. Two objectives and research questions respectively were stated to guide the study. Two hypotheses were also tested in the study. The study adopted a correlational design, and the population of the study was 98. Sample of the study was census which involves the use of the entire population. The instrument for data collection was researcher's structured modified 4-point Likert rating scale. The data collected for the study were analysed using Pearson Product Moment Correlation (PPMC) technique, while the hypotheses were tested for significance statistically using Spearman Rank Correlation analysis at 0.05 level of significance. The findings of the study revealed that there is a significant relationship between staff promotion and job satisfaction of librarians in libraries of federal universities in South-East geopolitical zone of Nigeria. The findings further revealed that there is also significant relationship between staff job security and job satisfaction of librarians in libraries of federal universities in South-East geo-political zone of Nigeria. The study recommended that staff promotion should be done regularly and as at when due to motivate the librarians to work hard in their workplaces. It is also recommended that librarians job security should be guaranteed at all times to ensure that they put in their best in the performance of their official duties to the benefit of their libraries.
\end{abstract}

Keywords: Job satisfaction, Librarians, Federal Universities, University libraries.

\section{INTRODUCTION}

Librarianship is generally considered to be concerned with the principle and practice of selecting, acquiring, organizing, disseminating and providing access to information in accordance with the specific needs of groups of people, individuals or corporate bodies. Most of the time, the feelings of librarians who perform these enormous tasks are not taken into consideration by the management of the libraries. According to Ranaweera, Li and Bodihinayake (2018), employees spend an extensive period of time at the working place, it is important to discover the opinions of individuals on their jobs and its inherent status. In other words, it is very necessary to know whether these librarians who work in libraries particularly academic libraries are satisfied with their jobs or not. This is necessary because if these librarians are not satisfied with their jobs, their productivity will not be impressive. 
According to Simon (2011)., if the librarian is to become an effective mediator between man and his graphic records, a trade school for finding a particular book on a particular shelf for a particular patron with a particular need, he would be doing his job badly if he does not possess a true mastery over the means of access to recorded knowledge. One of the key elements that have been linked to the success of any organization is the job satisfaction of the employees. Every organization depends on its employees to carry out its functions. For this reason, Oshagbemi (2000) asserts that the ability of any organization to achieve its goals depends on its capability to attract, retain, and even maintain competent and satisfied staff into its employment. It is in view of this that the author concluded that every organization that has goals to achieve should have satisfied and happy staff.

Job satisfaction means the extent to which an employee feels self-motivated, contentment and satisfied with his/her job. Specter (1997) defines job satisfaction to mean how contented an individual is with his/her job; whether he/she likes the job or not. Weiss (2002) argues that job satisfaction is an attitude that comes about as a result of either a positive or negative evaluation judgment one makes regarding one's job situation. Job satisfaction could be achieved either by intrinsic or extrinsic factors. Gazioglu and Tansel (2002) have also identified lack of job satisfaction as a predictor of quitting a job, while Iverson and Deery (2007) and Lum (2006) add that lack of job satisfaction could result in slowing down of work, job success, and job productivity; increase in workforce turnover, occupational accidents and complaints. It is on this basis that employees' job satisfaction in organizations has been receiving increasing attention.

The library, as have been noted by Ikonne and Onuoha (2015), is one of the key units of any educational institution and, especially, the University as it caters for the information needs of its users within and outside the University community. Job satisfaction of library workers should be considered crucial as it has to do with the appraisal of one's job or job experience. Considering the importance of this and for achieving its organizational goals and objectives, the library should ensure that its employees attain adequate job satisfaction.

Therefore, a worker feels satisfied when he/she is either rewarded and with promotion for jobs well done. A worker is also satisfied when he/she realizes that he/she has job security in his/her work place. Job promotion means the transfer of an employee to a job which pays more or one that carries some preferred status (Scott and Clothier, 1977). Job security is also defined as the assurance from the company or organization that their employees will remain with them for a reasonable period of time without being wrongly dismissed (Simon, 2011). When a worker is promoted, the worker tends to put in his/her best on the job for the realization of maximum goals and objectives of the organization. Again, when a worker realizes that his job is secured, he works very hard for the success of the organization. These two variables to a great extent influence job satisfaction of workers in every establishment. The study therefore examines the influence of job satisfaction of librarians in federal university libraries in South-East geopolitical zone of Nigeria.

\subsection{Statement of the Problem}

A lot of things are seen by researchers as the causative factors of job satisfaction or dissatisfaction in an organization. It could be the work environment, the administrative style of the chief executive, workers' promotion, job security, prompt payment of salaries, staff development or even regular internal posting in the organization. Absence of some or all these can lead to job dissatisfaction. Invariably, job dissatisfaction could lead to low productivity which will affect the maximization of profit by the organization. Librarians working in academic libraries need to be motivated in order to put in their best on their job. Any form of motivation which can lead to improved performance and provision of adequate services in the library could well be interpreted that the librarians are satisfied with their jobs. Job security and promotion of staff are seen as important factors that can lead to job satisfaction or dissatisfaction in academic libraries. It has not been ascertained on the extent at which job security and staff promotion can lead to job satisfaction of librarians particularly in federal universities in South-East geo-political zone of Nigeria and this made this study relevant. 


\subsection{Objectives of the Study}

The purpose of this study is to examine the factors influencing job satisfaction of the librarians in Federal University libraries in South East geo-political zone of Nigeria. Specifically the objective are:

1. To determine the relationship between job security and job satisfaction of librarians in libraries of federal universities in South-East geo-political zone of Nigeria; and

2. to determine the relationship between promotion and job satisfaction of librarians in libraries of federal universities in South-East geo-political zone of Nigeria.

\subsection{Scope of the Study}

This study focused on the factor influencing job satisfaction of librarians in Federal University libraries in South-East geo-political zone of Nigeria. The study is limited to five Federal University libraries in South-East Nigeria namely; Alex Ekwueme University Library, Ndufu-Alike, Ebonyi State; Federal University of Technology Owerri, Library, Imo State; Michael Okpara University of Agriculture, Umudike, Library, Abia State; University of Nigeria, Nsukka, Library, Enugu State and Nnamdi Azikiwe University, Awka Library, Anambra State.

The study also investigated the influence of job security, and promotions on job satisfaction of librarians in these universities.

\subsection{Research Questions}

The researcher posed the following research questions to guide the study:

i. What is the relationship between job security and job satisfaction of librarians in libraries, of federal universities in South-East geo-political zone of Nigeria?

ii. What is the relationship between promotion and job satisfaction of librarians in libraries of Federal Universities in South-East geo-political zone of Nigeria?

\subsection{Hypotheses}

The study formulated and tested the following null hypotheses at 0.05 level of significance:

Ho1: There is no significant coefficient of relationship between staff job security and job satisfaction of librarians in libraries of federal universities in South-East geo-political zone of Nigeria.

$\mathrm{Ho}_{2}$ : The coefficient of relationship between promotion and job satisfaction of librarians in libraries of federal universities in South-East geo-political zone of Nigeria is not significant.

\section{LITERATURE REVIEW}

Job satisfaction means a feeling of fulfillment or enjoyment that a person derives from his job. According to Mba Skoll (2019), job satisfaction is defined as the extent to which an employee feels self-motivated, contented and satisfied with his or her job. Spector (1997) defined job satisfaction as the pleasurable emotional state resulting from appraisal of one's job values. Again, Ranaweera, Li and Bodhinayake (2018) see job satisfaction as a perception of employees towards their own job and correlated aspects and how they measure their job in between satisfying to dissatisfying. In the view of Locke (2014), job satisfaction is a pleasurable or a positive emotional state resulting from the appraisal of one's job or job experience. Again, Fritzsche and Parrish (2005), affirm that job satisfaction is an indication of one's emotional reactions or state that emerges from one's cognitive appraisal of job experience to one's job. Job satisfaction is the extent at which an employee feels at home with the job which can lead to efficient productivity in an organization. A lot of factors can lead to job satisfaction or dissatisfaction. According to Salama and Courtney (2013), different variables predict employees' job satisfaction for different professions. This is due to the fact that different professions have different challenges and stressors which impact employees' job satisfaction. 
According to Okaro, Eze and Ohagwu (2010), job satisfaction is a complex scenario in nature and it is associated with a number of fundamental elements. Ikonne and Onuoha (2015), assert that job satisfaction is an important concept that can affect labour market behaviour as it has a great productivity, work effort, absenteeism, turnover rates and employee relations. The authors further stated that job satisfaction are one of the key elements that is often linked to the success of any organization. Every establishment be it big or small depends on its employees to carry out its functions. The manner at which these employees are treated by the organizations management can affect the staff either positively or negatively and also determine the productivity of the employees. The ability of any establishment to achieve its goals depends on its capability to attract, retain and even maintain competent staff into its employment (Oshagbemi, 2000). Lack of job satisfaction could lead to low productivity and this can affect the growth and profit of the organization. According to Lum (2006), lack of job satisfaction could result in slowing down of work, job success and job productivity, increase in workforce turnover, occupational accident and complaints.

There are many factors which could cause job satisfaction or dissatisfaction in any organization. According to lkonne and Onuoha (2015), it could be intrinsic or extrinsic factors. It is intrinsic factor when the employee is working because he/she want to work without attracting any monetary reward or gain that accrues from it. It could be extrinsic factor when an employee is performing his/her task in an organization because of the monetary or other forms of reward he/she may benefit at the end of the job. Intrinsic factor according to Wilson (2000), may matter significantly less than is sometimes assumed once a greater range of influence is introduced. Rose (2005) states extrinsic factors are external job related variables that would include salary, supervision and working conditions, rewards bestowed upon individuals by the organizations, supervisors or even peers or colleagues.

The feeling that there is adequate job security in an organization gives employees much confidence to put in their best on the job. Job security is one aspect of job satisfaction that is not really reward-related. According to Accredited Business (2019), having a stable company makes employees feel secure which helps to promote job satisfaction. Kraja (2015) defines job security as the knowledge that one's job is permanent as long as you want to be. Arabi (2000) also stated that job security is a feeling of having a proper job and the assurance of its continuity in future as well as the absence of threatening factors. Khan, Nawaz, Allem and Hameed (2012) stated that job security is significantly related to job satisfaction and this can lead to maximum performance. Again Yousef (1998) asserts that job security is positively correlated to job satisfaction and performance. Workers tend to perform maximally when they have the guarantee that their jobs are stable or secured. Guaranteed job security is an antidote to job dissatisfaction.

Staff promotion is a term which conveys a change in status and calls for a greater responsibility and usually involves greater pay and better conditions of service and therefore a higher status or rank (Mamoria \& Ganker, 2011). Pillai and Bagavathi, 2010) describe staff promotion as changing a worker to a higher post with more responsibilities and higher salary. Promotion according to Vicky (2018) refers to an upward movement of an employee from one job to another job, which commands higher pay scale and allowances, upper status and prestige, more authority, power and responsibilities to rise. Again, Heathfield (2019) states that promotion is the advancement of an employee from one job position to another job position that has a higher salary range, higher level of job title and often more and higher level or job responsibility in organizations. Promotion is usually given to employees in the same organization or establishment. It is seen as an internal upward mobility of an employee. 
Promotion is not only a way to add more responsibilities to an employee but is a major form of boosting employe motivation and morale (Anastasia, 2015). The author further stated that there are many benefits or advantages of promoting employees regularly for their efforts.

They include:

i. Promotion recognizes and improves employee performance, ambition and hard work;

ii. promotion boost motivation and increase loyalty of employees;

iii. promotion encourages retention;

iv. promotion develops healthy competitive spirit at the work place;

v. it grooms leaders for the future; and

vi. it reduces employee resistance and discontent.

According to Onuoha (2007), promotion has very positive influence or significant job satisfaction of employees in organizations. The author further stated that when workers are promoted, they feel more satisfied and be willing to contribute more to the development of the organization. Evans and Rugaos (2012) also stated that promotion helps organizations to maintain stable growth in production. The authors further stated that promotion has significant relationship with job satisfaction.

\section{METHODOLOGY}

Co-relational research design was adopted for the study. The population of the study was 98which was made up of all the librarians working in federal university libraries in South-East geo-political zone of Nigeria namely; Imo, Enugu, Anambra, Abia, Ebonyi States. The entire population was used because it was accessible to the researcher. A 4point Likert rating scale was used for data collection. A total number of 98 copies of rating scale were distributed to the librarians and all were duly completed and returned to the researcher. Data collected for the study were analyzed using Pearson Product Moment Correlation (PPMC) statistical method. This provided both the descriptive and inferential data for answering the research questions. Spearman Rank Correlation Analysis was used to test the hypotheses at 0.05 level of significance.

\section{RESULTS AND DISCUSSION}

\section{Distribution and Collection of Instrument}

A total of ninety-eight (98) copies of the instrument were distributed to the entire sample of the study which was 98 , and all the copies distributed were dully completed and returned to the researcher. This represents $100 \%$ return rate.

Analysis of demographic variables of respondents

Table 1: Demographic profile of respondents

\begin{tabular}{lll}
\hline Gender & Frequency & Percentage \\
\hline Male & 34 & 34.7 \\
Female & 64 & 65.3 \\
Total & 98 & $100 \%$ \\
Highest Academic Qualification & & \\
BLS & 12 & 12.2 \\
MLS & 63 & 64.3 \\
Ph.D & 23 & 23.5 \\
Total & 98 & $100 \%$
\end{tabular}


Other Qualifications (LRCN)

\section{Years of Working Experience}

\begin{tabular}{lll} 
Years of Working Experience & & \\
$1-5$ years & 20 & 20.4 \\
$6-10$ & 33 & 33.7 \\
$11-15$ & 19 & 19.4 \\
$16-20$ & 17 & 17.3 \\
21 years and above & 9 & 9.2 \\
Total & 98 & $100 \%$ \\
& & \\
\hline Department & & 11.2 \\
Cat \& class & 11 & 8.2 \\
Circulation & 8 & 11.2 \\
ICT/Digital lib. & 11 & 8.2 \\
Fac./Dept' lib & 8 & 3.1 \\
Collection Devpt. & 3 & 9.2 \\
Serial & 9 & 7.1 \\
Reference & 7 & 1.0 \\
Documents & 1 & 2.0 \\
Literacy and Information & 2 & 1.0 \\
Research \& Devp. & 1 & $62.2 \%$ \\
\hline Total & 61 & \\
\hline
\end{tabular}

21 21.4

The analysis of data in Table 1 showed that $34(34.7 \%)$ of the respondents are males while $64(65.3 \%)$ of the respondents are females. Based on this analysis, it can be inferred that there are more female librarians in the libraries surveyed than male librarians. The analysis further showed that $12(12.2 \%)$ of the respondents possess Bachelor of Library and Information Science (BLS) degree as their highest academic qualification, 63 (64.3\%) of respondents possess Master of Library and Information Science (MLS) degree, $23(23.5 \%)$ of respondents possess Doctor of Philosophy (Ph.D) in Library and Information Science. Out of the 98 respondents, only 21 (21.4\%) of them indicated that they are certified librarians by Librarians Registration Council of Nigeria (LRCN).

On the respondents years of working experience, the analysis showed that $20(20.4 \%)$ of the respondents have between 1-5 years of working experience, $33(33.7 \%)$ of the respondents have 6-10 years working experience, 19 $(19.4 \%)$ of respondents have 11-15 years working experience, $17(17.3 \%)$ of the respondents have 16-20 years working experience and $9(9.2 \%)$ of the respondents have 21 years and above working experience. Again, the analysis further showed that $11(11.2 \%)$ of respondents work in the cataloguing and classification and ICT/digital sections of their libraries respectively, $8(8.2 \%)$ of the respondents work in the circulation and faculty/departmental sections of their libraries respectively. While $3(3.1 \%)$ of respondents work in the collection development section of their libraries. Another $9(9.2 \%)$ of respondents work in the serial section of the library and $7(7.1 \%)$ of respondents work in the reference section. Only $1(1 \%)$ of respondent work in the document, research and development sections respectively, while $2(2 \%)$ respondents indicated that they work in the literacy and information section of their libraries. 


\section{Research Question 1: What is the coefficient of relationship between staff promotion and job satisfaction of librarians in libraries of Federal Universities in South-East geo-political zone of Nigeria?}

The result in Table 1 presents the correlation analysis result between staff promotion and job satisfaction of librarians in libraries of Federal Universities in South-East geo-political zone of Nigeria.

Table 1: Correlation Analysis result indicating the level of relationship between staff promotion and job satisfaction of librarians

\section{Correlations}

\begin{tabular}{lllr|r} 
& & \multicolumn{1}{c}{$\begin{array}{c}\text { Staff } \\
\text { Appraisal/Promo } \\
\text { tion }\end{array}$} & \multicolumn{1}{c}{$\begin{array}{c}\text { Staff Job } \\
\text { Satisfaction }\end{array}$} \\
\hline Spearman's rho & Staff Appraisal/Promotion & Correlation Coefficient & 1.000 & .273 \\
\cline { 3 - 6 } & & Sig. (2-tailed) & .98 & .006 \\
\cline { 2 - 5 } & Staff Job Performance & Correlation Coefficient & .273 & 98 \\
\cline { 3 - 6 } & & Sig. (2-tailed) & .006 & 1.000 \\
\cline { 3 - 6 } & $\mathrm{N}$ & 98 & 98 \\
\hline
\end{tabular}

Source: SPSS 25 Correlation Analysis Result Output

The result as shown in Table 1 presents the correlation analysis result indicating the level of relationship between staff promotion and job performance of librarians. The result showed a correlation coefficient of 0.273 being about $27.3 \%$ level of relationship existing between staff promotion and job satisfaction of librarians. This relationship existing between staff promotion and job satisfaction of librarians is said to be positive and small/low relationship.

\section{Hypothesis One}

$\mathrm{H}_{.01}$ : There is no significant coefficient relationship between staff promotion and job satisfaction of librarians in libraries of Federal Universities in South-East geo-political zone of Nigeria.

The result in Table 1 also presented the p-value in determining if the relationship that exists between staff promotion and job satisfaction is significant. The result presents that a p-value of 0.006 exists between staff promotion and job satisfaction of librarians, therefore indicating that a significant relationship exist between staff promotion and job satisfaction of librarians. The null hypothesis is therefore rejected and the alternative hypothesis stating that there is a significant relationship between staff promotion and job satisfaction of librarians in libraries of Federal Universities in South-East geo-political zone of Nigeria is accepted. Therefore, it is concluded that a significant relationship exist between staff promotion and job satisfaction of librarians in libraries of Federal Universities in South-East geopolitical zone of Nigeria. This finding corroborates earlier findings by Onuoha (2007) who stated that promotion has positive influence or significance on job satisfaction. Evans and Rugaos (2012) also stated that promotion has significant relationship with job satisfaction. This means that employees are satisfied when promoted by their organization and are willing to contribute positively towards the growth of the organization.

Research Question 2: What is the coefficient of relationship between job security and job satisfaction of librarians in libraries of federal Universities in South-East geo-political zone of Nigeria?

The result in Table 2 presents the correlation analysis result between job security and job satisfaction of librarians in Libraries of Federal Universities in South-East geo-political zone of Nigeria. For the purpose of determining the coefficient of relationship between job security and job satisfaction of librarians, a correlation analysis operation was performed. 
Table 2: Correlation Analysis Result indicating the level of relationship between job security and job satisfaction of librarians

\section{Correlations}

\begin{tabular}{lllr|r} 
& & & \multicolumn{2}{c}{$\begin{array}{c}\text { Staff Job } \\
\text { Satisfaction }\end{array}$} \\
\hline Spearman's rho & Staff Job Security & Correlation Coefficient & 1.000 & .243 \\
\cline { 3 - 5 } & Sig. (2-tailed) & $\cdot$ & .016 \\
\cline { 2 - 5 } & Staff Job Performance & Correlation Coefficient & 98 & 98 \\
\cline { 2 - 5 } & Sig. (2-tailed) & .243 & 1.000 \\
\cline { 2 - 5 } & N & .016 & 98 \\
\hline
\end{tabular}

Source: SPSS 25 Correlation Analysis Result Output

The result disclosed in Table 2 showed the correlation analysis result indicating the level of relationship between job security and job satisfaction of librarians. The result showed a correlation coefficient of 0.243 being about $24.3 \%$ level of relationship existing between staff job security and job satisfaction of librarians. This relationship existing between staff job security and job satisfaction of librarians is said to be positive and small/ low relationship.

\section{Hypothesis Two}

H.02: The significant coefficient of relationship between staff job security and job satisfaction of librarians in libraries of federal universities in South-East geo-political zone of Nigeria is not significant.

The result in Table 2 also presented the p-value in determining if the relationship that exists between staff job security and job satisfaction is significant. The result presents that a p-value of 0.016 exists between staff job security and job satisfaction of librarians, therefore indicating that a significant relationship existed between staff job security and job performance of librarians. The null hypothesis is therefore rejected and the alternative hypothesis stating that there is a significant coefficient relationship between staff job security and job satisfaction of librarians in libraries of Federal Universities in South-East geo-political zone of Nigeria is accepted.

Hence it can be concluded that a significant coefficient relationship exist between staff job security and job satisfaction of librarians in libraries of Federal Universities in South-East geo-political zone of Nigeria. This finding affirmed earlier studies by Khan, Nawaz, Aleem and Hameed (2012) who stated that job security is significantly related to job satisfaction and this can lead to maximum performance in organizations. Again, Yousef (1998) asserts that job security is positively correlated to job satisfaction and performance. 


\section{CONCLUSION/RECOMMENDATION}

This study examined factors influencing job satisfaction of librarians in Federal Universities in South-East geopolitical zone of Nigeria. Based on the findings of the study, it could be concluded that there are important factors which influence librarians job satisfaction in university libraries. Among these factors were staff promotion and job security. Librarians working in federal university libraries in South-East geo-political zone of Nigeria are highly satisfied with their jobs when they are promoted from lower rank to a higher rank. Again, when these librarians have the full assurance that their jobs are guaranteed or secured, they feel satisfied and in return work hard for the benefit of their libraries. However, when these two factors are not obtainable, dissatisfaction will always set in thereby resulting to low performance and productivity. Based on these findings, the library administrators should look in for more ways to motivate their librarians because when they are well motivated their performance will definitely yield to high productivity, the researchers recommended that librarians' promotion should be done regularly and as and when due, also librarians job security should be adequately guaranteed at all times. The knowledge of the presence of these official benefits will no doubt spur librarians in federal university libraries in South-East geo-political zone of Nigeria to perform maximally in their work places.

\section{REFERENCES}

1. Accredited Business (2019). What is job satisfaction: Definition, causes and factors. Retrieved from: http://www.study.com/academics on 24/05/19.

2. Anastasia, B.T. (2015). When and how to promote your employees. Retrieved from: http://www.cleverism.com on 15/05/19.

3. Arabi, S.M. (2000). Strategies, plans and guidelines to achieve job security. Journal of Management Studies. Quarterly: 28-37.

4. Evans, E.B. \& Rugaos, S.P. (2012). Another look at performance appraisal in library. Retrieved from: www.Unesco.org/wcbwoi-Id/i-amp/html. Accessed 14 January, 2012.

5. Fajana, S. (2002). Human resources management: An introduction. Labofin and Company, Lagos: (Citation Time(5): 1).

6. Fritzsche, B.A. and Parrish, T.J. (2005). Theories and Research on Job Satisfaction. In: Brown, R. and Lent, R., Eds., Career Development and Counseling: Putting Theory and Research to Work, Wiley, New York, 180-202. [Citation Time(s):1]

7. Gazioglu, S. and Tansel, A. (2002). Job Satisfaction in Britain: Individual and Job-Related Factors.

Economic Research Centre Working Papers in Economics 03/03. http://ideas.repec.org/p/met/wpaper/0303.html [Citation Time(s):1]

8. Heathfield, S. (2019). A promotion rewards an employee for work contribution. Retrieved from: www.thebalancecarers.com. On 24/05/19.

9. Ikonne, C.N. \& Onuoha, U.D. (2015). Factors influencing job satisfaction of librarians in federal and state university libraries in Southern Nigeria. Open Access Library Journal. Retrieved from: http://www.dx.doi.org/104236/oalib.1101337 on 24/05/19.

10. Iverson, R.D. and Deery, M. (2007). Turnover Culture in the Hospitality Industry. Human Resource Journal, 7, 471-482. [Citation Time(s):1]

11. Khan, A.H., Nawaz, M.M., Aleem, M. \& Hameed, W.A. (2012). Impact of job satisfaction on employee performance: An empirical study of autonomous medical institutions in Pakistan. African Journal of Business Management. 6(7): 2697-2705. Available online; http://www.academicjournals.org/AJBM Accessed in September, 2013.

12. Kraja, G. (2015). Job security and performance: case study of the Albanian Public Administration. Academic Journal of Interdisciplinary Studies. 4(2): 10-25 
13. Locke, E.A. (2014). The Nature and Causes of Job Satisfaction: Handbook of Industrial and Organizational Psychology, Chicago,

Rand

McNally. http://scholar.google.com/scholar?q=Edwin+A.+Locke's+Range+of+Affect+Theory+(1976)\&hl=en\&as_sdt=0 \&as_vis=1\&oi=scho [Citation Time(s):2]

14. Lum, L.K. (2006). Explaining nursing turnover culture intent: Job satisfaction or organizational commitment. Journal of Organizational Behaviour, 19:305-320.

15. Lum, L.K. (2006). Explaining Nursing Turnover Intent: Job Satisfaction or Organizational Commitment. Journal of Organizational Behavior, 19, 305-320. [Citation Time(s):1]

16. Mamoria, C.B. \& Ganker, S.V. (2011). Personnel Management: Text and Cases. Mumbai: Himalaya Publishing House.

17. MBA SKOOL (2019). Job satisfaction. Retrieved from: http://www.mbaskool.com on 24th May, 2019.

18. Murray, R.A. (1999). Job Satisfaction of Professional and Paraprofessional Library Staff at the University of North Carolina at Chapel Hill. A Master's Paper for the M.S. in L.S. Degree. [Citation Time(s):1]

19. Okaro, O., Eze, C.U. \& Ohagwa, C.C. (2010). Survey of job satisfaction among Nigerian Radiographers in South-Eastern Nigeria. European Journal of Scientific Research; 39(3): 448-456.

20. Onuoha, U.D. (2007). Perception of performance appraisal as a tool for enhanced productivity and career advancement in three university libraries in Ogun State, Nigeria. Retrieved from: www.webpages.ui daho.edu/ mbolin/tella2.html on 20 March 2012.

21. Oshagbemi, T. (2000). How satisfied are academies with their primary tasks of teaching, research and administration and management. International Sustainable in Higher Education. 1:124-136.

22. Pillai, R.S.N. \& Bagavathi, B.S. (2010).Office management and productivity in academic and public libraries in Botswana. Library Management. 19 (1):49-58

23. Ranaweera, R.A.A.S., Li, S. \& Bodhinayake, D. (2008). Job satisfaction of library staff: A study based on university libraries in Sri Lanka. International Journal of Human Resources Studies. 8(3):53-59.

24. Rose, M. (2005). Job satisfaction in Britain: Coping with complexity. British Journal of Industrial Relations. 43:455-467.

25. Salama, A.M. and Courtney, L. (2013). The Impact of the Spatial Qualities of the Workplace on Architects Job Satisfaction. International Journal of Architectural Research, 7, 52-64. http://archnet.org/library/documents/one-document.jsp?document_id=13526 [Citation Time(s):1]

26. Scott, W. \& Clothier (1977). Personnel Management: Principles, Practices and Point of view. New Delhi: McGrawHill Publishing Co.

27. Simon, N.T. (2011). What is job security (and does it really exist?). Retrieved from: http://www.simonstapleton.com/workpress/2011/01/12/what-is-job-security-and-does-it-reallyexist.html on $12 / 5 / 18$.

28. Spector, P.E. (1997). Job satisfaction: Application, assessment, causes and consequences. Thousand Oaks CA: Sage.

29. Vicky, S.O. (2018). Promotion of employee in an organization. Retrieved from: www.yourarticlelibrary.com. On 15/05/19.

30. Weiss, H.M. (2002). Deconstructing job satisfaction separating evaluation, beliefs and affective experiences. Human Resources Management Review. 12:1-22. Available at http://dx.doi.org/10.1016/S1053-4822(02)00045-1.

31. Wilson, J.R. (2000). Fundamentals of Ergonomics in theory and practice. Applied Ergonomics. 31:557-567. Retrieved from: http://www.dx.doi.org/10.1016/50003-6870(00)00034-X on 23/05/19.

32. Yousef, D.A. (1998). Satisfaction with job security as a predictor of organizational commitment and job performance in a multicultural environment. International Journal of Manpower. 19 (3), 184 - 194. Available online: http://www.emeraldinsight-com/journal.htm/. Accessed in August 17, 2016. 